\title{
IMPACT OF WATER STRESS DURING DIFFERENT GROWTH STAGES ON TOMATO YIELD UNDER VARIOUS IRRIGATION SYSTEMS \\ Shalaby, A. A. ${ }^{*}$ A. F. Saad ${ }^{* *}$ and A. M. A. Mokhtar* \\ ${ }^{*}$ Department of Soil Chemistry and Physics, Desert Research Center, Egypt. \\ ${ }^{* *}$ Department of Soils and Water Sciences, Faculty of Agriculture, Alexandria University, Egypt.
}

\begin{abstract}
Field experiment was carried out at Maryout Experimental Station Farm, Desert Research Center during summer season 2007. The field experiment amid to study the impact of water stress levels of 100, 75 and $50 \%$ from crop evapotranspiration, ETc during development, flowering and harvesting stages on some plant growth parameters and yield of tomatoes (Lycopersicon esculentum, mill., cultivator 888) in calcareous sandy clay loam soil. Drip and gated-pipe irrigation systems were used in this investigation. Generally, the obtained results revealed that the plant height values at harvesting growth stage under drip irrigation system were not significantly lower than those obtained under gated pipe irrigation system. The plant height values subjected to irrigation water stress levels 100, 75 and $50 \%$ ETc during different growth stages were significantly decreased with increasing irrigation water stress levels under the studied irrigation systems. Tomatoes leaf water potential values, $-\mathrm{kPa}$, at harvesting growth stage were significantly increased with increasing irrigation water stress levels subjected during different growth stages under studied irrigation systems. The fruit yield of tomatoes as affected by irrigation water stress levels subjected during different growth stages under drip irrigation system were significantly higher than that obtained under gated pipe irrigation system. Also, fruit yields of tomatoes were significantly decreased with increasing irrigation water stress levels under studied irrigation systems, especially at water stress level of $50 \%$ ETc. For the fruit yield, the results showed that the flowering growth stage of tomatoes subjected to irrigation water stress levels is more sensitive than other growth stages under studied irrigation systems. Consequently, tomato plants subjected to water stress levels during flowering growth stage achieved the lowest net revenues and invested pound return.

Keywords: water stress, drip irrigation, gated pipe, growth stages, leaf water potential and tomato yield
\end{abstract}

\section{INTRODUCTION}

In arid and semi arid regions, the impact of water stress on plant growth parameters and yield is depending on the quality and amount of irrigation water, crop, plant growth stage, soil type, climate and irrigation system as well as the time of exposure to water stress. Doorenbos and Kassam (1979) reported that the water stress effects on growth and yield are depending on plant species and variety. Moreover, sensitivity to drought varies by the development stage. While, El-Neomani et al., (1990) stated that, for corn, water stress during the rapid vegetative stage restricted plant 
growth. On the other hand, Cakir (2004) concluded that sensitive tasselling stage is strongly affected by water stress than other different growth stages.

Yuan et al., (2003) reported that potato is a relatively sensitive plant to water stress and that soil water is one of most important factors affecting the yield and the quality. They tested the effect of different amounts of irrigation water applied to potato crop: $0.25,0.50,0.75,1.0$ and 1.25 of water surface pan evaporation, and found that plant height increased with increasing the amount of applied irrigation water. On the other hand, AlMohammadi and Al-Zu'bi (2011) conducted an experiment under greenhouse conditions to evaluate the optimum combinations of irrigation and fertilizer levels to attain the best yield and quality of tomato crop, and concluded that the irrigation and fertilizer levels had significant effects on the number of flowers per plant; however, plant height was not affected significantly by any treatment. On the contrary, Incalcaterra, et al., (2003) studied the influence of the volume of irrigation water on winter melon (Cucumis melo inodorus Naud) grown under plastic tunnel using three volumes of irrigation water $(20,30,40$ liter / plant). Water was provided by a single application after 50 days from transplanting. The vegetative growth parameters at 60 and 70 days after transplanting were slightly influenced by the treatments tested. After 80 days of transplanting, plant height was positively affected by increasing the amount of irrigation water, but significantly reduced as salinity increased. Katerji et al. (1998) studied the effect of tomato growth under both water and salt stresses and they reported that the behavior of the tomato plant under saline conditions appears to be similar to that under drought conditions.

Fisher and $\mathrm{Nel}$ (1990) studied the effect of water stress on tomato growth and yield components; they reported a lack of response of tomato leaf growth to water stress, whereas yield and fruit size decreased with the increase of stress. Mathieu et al., (2007) in an experiment conducted in summer of 2003 and 2004 to study the effect of withholding the irrigation on yield of a drip irrigated plants under plastic culture system. Irrigation treatments initiated at tomato planting $\left(\mathrm{S}_{0}\right)$, after transplant establishment $\left(S_{1}\right)$, at first flower $\left(S_{2}\right)$, at first fruit $\left(S_{3}\right)$, and at fruit ripening $\left(S_{4}\right)$. In addition treatment received only enough water to apply fertigation with holding drip irrigation for a short period $\left(\mathrm{S}_{2}-\mathrm{S}_{3}\right)$ increased tomato marketable yield by 8$15 \%$, fruit number by $12-14 \%$ and reduced amount of irrigation water by $20 \%$ compared to the $\mathrm{S}_{0}$ treatment.

Phene et al., (1987) studied the effect of irrigation frequency and fertigation process under drip irrigation system and demonstrated significant yield increases in tomatoes with the use of high frequency and precise fertility management.

Abdel Gawad et al., (2005) mentioned that irrigating tomato using drip irrigation system produces higher yield than the traditional surface irrigation method.

The objectives of the present study are to investigate the impact of irrigation water stress subjected during different growth stages on some growth parameters and total yield of tomatoes using drip and gated-pipe irrigation systems. 


\section{MATERIALS AND METHODS}

Field experiment was carried out at Maryout Experimental Station Farm, Desert Research Center during summer season 2007. The station located at $30^{\circ} 55^{\prime} 71^{\prime \prime} \mathrm{N}, 29^{\circ} 51^{\prime} 67^{\prime \prime} \mathrm{E}$ and $50 \mathrm{~m}$ above sea level. Particle size distribution was determined by pipette method according to Kulte (1986), total carbonate was determined as $\mathrm{CaCO}_{3} \%$ by using Collin's Calcimeter described by Jackson (1967) while the bulk density was determined by core method accordingly, Kulte (1986), the soil was classified as calcareous sandy clay loam (59 \% sand, $13 \%$ silt and $28 \%$ clay) with $29.50 \%$ total calcium carbonate and $1370 \mathrm{Mg} / \mathrm{m}^{3}$ bulk density. Soil salinity (ECe) as total soluble salts were determined in the soil saturation extract, Richards (1954). Soil reaction $(\mathrm{pH})$ was measured in soil paste using $\mathrm{pH}$ meter according to Page (1982), the electric conductivity of saturated soil paste extract (ECe) was 2.13 $\mathrm{dS} \mathrm{m}^{-1}$ and soil reaction, $\mathrm{pH}$, value was 8.2 as well as sodium adsorption ratio (SAR) value was 2.35 , the soil is non saline and non alkali. Crop water requirement is calculated using CROPWAT 8.0, for windows, computer program using Penman-Monteith equation using the metrological data of Maryout Experimental Station, Table (1). The duration of stages and the crop factor of tomatoes were used 35,45 and 30 days and $0.60,1.15$ and 0.80 at development, flowering and harvesting growth stages respectively, according to Allen, et al. (1998).

Table(1):Metrological data of Maryout Research Station, Desert Research Center.

\begin{tabular}{|l|c|c|c|c|c|c|}
\hline Month & $\begin{array}{c}\text { Maximum } \\
\text { Temperature, } \\
\text { o-C }\end{array}$ & $\begin{array}{c}\text { Minimum } \\
\text { Temperature, } \\
\text { oC }\end{array}$ & $\begin{array}{c}\text { Humidity } \\
\%\end{array}$ & $\begin{array}{c}\text { Wind } \\
\mathbf{s p e e d} \\
\mathbf{k m} / \mathbf{d}\end{array}$ & $\begin{array}{c}\text { Sunshine } \\
\mathbf{H}\end{array}$ & $\begin{array}{c}{ }^{\text {} E T o, ~} \\
\mathbf{m m} / \mathbf{d a y}\end{array}$ \\
\hline January & 17.5 & 7.5 & 70.0 & 343.0 & 6.6 & 2.46 \\
February & 17.5 & 7.5 & 70.0 & 343.0 & 7.6 & 2.70 \\
March & 22.5 & 12.5 & 60.0 & 354.2 & 8.3 & 4.30 \\
April & 25.0 & 12.5 & 60.0 & 334.4 & 9.2 & 5.10 \\
May & 27.0 & 15.0 & 60.0 & 311.0 & 10.4 & 5.73 \\
June & 30.0 & 20.0 & 60.0 & 311.0 & 11.9 & 6.68 \\
July & 30.0 & 22.5 & 60.0 & 338.7 & 12.0 & 6.86 \\
August & 37.0 & 25.0 & 60.0 & 337.0 & 11.3 & 7.73 \\
September & 33.0 & 24.0 & 60.0 & 334.4 & 10.7 & 6.63 \\
October & 28.5 & 20.0 & 60.0 & 337.8 & 9.2 & 5.09 \\
November & 25.0 & 19.0 & 62.0 & 338.7 & 7.4 & 3.92 \\
December & 21.0 & 14.0 & 70.0 & 342.1 & 6.5 & 2.79 \\
\hline
\end{tabular}

${ }^{*}$ ETo, potential Evapotranspiration was calculated according to CROPWAT 8.0, for windows, computer program using Penman-Monteith equation.

Tomato seeds (Lycopersicon esculentum, mill., cultivar 888) were planted in seedling plats, filled with mixture of peatmos and vermiculite. Antifungi were used to prevent fungus growth in the planting media. The plates were irrigated with fresh water $(0.4 \mathrm{dS} / \mathrm{m})$ to have a good establishment. Nutrients solutions were used to encourage seeds growth. Seeds were planted in the plates on $1^{\text {st }}$ April, the seedlings transported to the field 
calcareous sandy clay loam soil after 30 days. Different treatments were applied after 5 days from the transporting date. Soil was (before planting) ploughed and mixed with mono calcium phosphate at a rate of $480 \mathrm{~kg} / \mathrm{ha}$ was also applied. The agronomic practices including weed and pest control followed as recommended for tomato production. Nitrogen fertilizers were applied at a rate of $280 \mathrm{~kg} \mathrm{~N} / \mathrm{ha}$, and K fertilizers at a rate of $175 \mathrm{~kg} \mathrm{~K} / \mathrm{ha}$. Mixer of $\mathrm{FeSO}_{4}, \mathrm{MnSO}_{4}, \mathrm{ZnSO}_{4}$, and $\mathrm{CuSO}_{4}$ was applied as foliar spray. Foliar spray of some weeds control and antifungal applied for diseases control. The harvest date was on $23^{\text {th }}$ August.

Drip and gated pipe irrigation systems were used in this investigation. For the irrigation systems, the main irrigation line was $63 \mathrm{~mm}$, and the sub main lines were $16 \mathrm{~mm}$ in diameter; the length of sub main lines was $9 \mathrm{~m}$. The space between plants was $0.5 \mathrm{~m}$ with distance between rows of $1 \mathrm{~m}$. Water meters installed to measure the amount of applied water for each treatment. For each irrigation system, 3 irrigation water stress levels of 100 (no water stress), 75 , and $50 \%$ from crop evapotranspiration (ETc) and 3 growth stages subjected to irrigation water stress levels, during development (d), flowering (f) and harvesting (h). The experiment was irrigated by water having $2.81 \mathrm{dSm}^{-1}$ and $12.15 \mathrm{SAR}$. The experimental design was completely randomized with three replications. Each irrigation system consisted of 7 treatments with applied irrigation water levels subjected during the different growth stages as follows.

$\mathrm{T}_{1} 100$ (control): the plants were irrigated by the irrigation water depth of $100 \%$ ETc during the season (no water stress).

T2 75 - D: the plants were irrigated by the irrigation water depth of $75 \%$ ETc subjected during the development growth stage and irrigated by the irrigation water depth of $100 \%$ ETc during the other growth stages.

T3 75 - F: the plants were irrigated by the irrigation water depth of $75 \%$ ETc subjected during the flowering growth stage and irrigated by the irrigation water depth of $100 \%$ ETc during the other growth stages.

T4 $75-\mathrm{H}$ : the plants were irrigated by the irrigation water depth of $75 \%$ ETc subjected during the harvesting growth stage and irrigated by the irrigation water depth of $100 \%$ ETc during the other growth stages.

T5 50 - D: the plants were irrigated by the irrigation water depth of $50 \%$ ETc subjected during the development growth stage and irrigated by the irrigation water depth of $100 \%$ ETc during the other growth stages.

T6 50 - F: the plants were irrigated by the irrigation water depth of $50 \%$ ETc subjected during the flowering growth stage and irrigated by the irrigation water depth of $100 \%$ ETc during the other growth stages.

T7 50 - $\mathrm{H}$ : the plants were irrigated by the irrigation water depth of $50 \%$ ETc subjected during the harvesting growth stage and irrigated by the irrigation water depth of $100 \%$ ETc during the other growth stages.

Crop water requirement was calculated using CROPWAT 8.0, for windows, computer program using Penman-Monteith equation using the metrological data of Maryout Experimental Station, Table (1). The length of stages and the crop factor of tomatoes were used 35,45 and 30 days and $0.60,1.15$ and 0.80 at development, flowering and harvesting growth stages, respectively, according to Allen, et al. (1998). The irrigation system 
efficiencies are 85 and $65 \%$ for drip and gated pipe irrigation systems, respectively, and the leaching requirements were calculated according to Doorenbos and Pruitt (1984). Data in Table (2) show the depth of irrigation water and the time of water stress levels 100, 75 and $50 \%$ from crop evapotranspiration (ETc) subjected during development (d), flowering (f) and harvesting $(\mathrm{h})$ growth stages.

Table (2):Crop water requirement, ETc, of tomato plants affected by irrigation water stress levels from \% ETc subjected during development, flowering and harvesting growth stages under studied irrigation systems.

\begin{tabular}{|c|c|c|c|c|}
\hline \multirow{3}{*}{$\begin{array}{l}\text { Irrigation water } \\
\text { stress levels } \\
\text { (\% ETc) }\end{array}$} & \multirow{3}{*}{$\begin{array}{l}\text { Treatment } \\
\text { stage }^{\star}\end{array}$} & \multicolumn{3}{|c|}{$\begin{array}{c}\text { ETc, } \\
\mathrm{mm} / \mathrm{growth} \text { stage }\end{array}$} \\
\hline & & \multicolumn{3}{|c|}{ Growth stage } \\
\hline & & d & $f$ & $\mathbf{h}$ \\
\hline \multirow{3}{*}{100} & $\mathrm{D}$ & 125.46 & 350.66 & 180.65 \\
\hline & $\mathrm{F}$ & 125.46 & 350.66 & 180.65 \\
\hline & $\mathrm{H}$ & 125.46 & 350.66 & 180.65 \\
\hline \multirow{3}{*}{75} & $\mathrm{D}$ & 94.10 & 350.66 & 180.65 \\
\hline & $\mathrm{F}$ & 125.46 & 263.00 & 180.65 \\
\hline & $\mathrm{H}$ & 125.46 & 350.66 & 135.49 \\
\hline \multirow{3}{*}{50} & $\mathrm{D}$ & 62.73 & 350.66 & 180.65 \\
\hline & $\mathrm{F}$ & 125.46 & 175.33 & 180.65 \\
\hline & $\mathrm{H}$ & 125.46 & 350.66 & 90.33 \\
\hline
\end{tabular}

* The plants subjected to irrigation water stress levels, \% ETc during different growth stages.

Plant height, $\mathrm{cm}$, was measured at harvesting growth stage. Leaf water potential (- $\mathrm{kPa})$ was determined with a portable pressure chamber apparatus (Soil Moisture Equipment Corp, Santa Barbara, CA, USA) for predawn using the fourth leaf in the plant at harvesting growth stage. Total yield, $\mathrm{kg} /$ plant, was determined at harvesting growth stage.

Analysis of variance by 3 Way Completely Randomized was used to test the degree of variability among the obtained data. Least significant difference (LSD) test was used for the comparison among treatments means, Steel and Torrie (1980). Cohort computer program was used for the statistical analysis, version 6.400 . 


\section{RESULTS AND DISCUSSION}

\section{Plant height}

Generally, results obtained revealed that plant height values, $\mathrm{cm}$, at harvesting stage under drip irrigation system were not significant and lower than that obtained under gated pipe irrigation system, Table (3) and Fig.(1). Also, the data show that plant height values at the end of harvesting growth stage subjected to irrigation water stress levels 100, 75 and $50 \%$ ETc during development, flowering and harvesting stages were significantly decreased with increasing irrigation water stress levels under studied irrigation systems. This decrease might be attributed to increasing salt accumulation in soil of active root zone with increasing applied irrigation water stress levels. |These results are in agreement with those obtained by Yuan et al., (2003) and Incalcaterra, et al., (2003). Under drip irrigation system, decrease percentage of plant height values relative to control treatment were 18.4, $13.8 \& 9.6 \%$ and $33.1,18.4 \& 14.3 \%$ for the plants subjected to irrigation water stress levels 75 and $50 \%$ ETc during the development, flowering and harvesting stages, respectively. Under gated pipe irrigation system, decrease percentage of plant height values relative to control treatment were 11.0, 14.3 \& $11.0 \%$ and $33.1,18.2 \& 17.2 \%$ for the plants subjected to irrigation water stress levels 75 and $50 \%$ ETc during the development, flowering and harvesting stages, respectively. Results obtained revealed that the development growth stage of tomatoes subjected to irrigation water stress levels is more affected than other growth stages under studied irrigation systems.

Table(3): Plant growth parameters at harvesting stage and total yield as affected by irrigation water stress levels \% ETc subjected during different growth stages under studied irrigation systems.

\begin{tabular}{|c|c|c|c|c|c|c|c|c|c|}
\hline \multirow{3}{*}{$\begin{array}{l}\text { Irrigation water } \\
\text { stress levels, } \\
\% \text { ETc }\end{array}$} & \multirow{2}{*}{\multicolumn{3}{|c|}{$\begin{array}{c}\text { Plant height, } \\
\text { Cm } \\
\text { Treatment stage }\end{array}$}} & \multirow{2}{*}{\multicolumn{3}{|c|}{$\begin{array}{c}\text { Leaf water potential, } \\
-\mathrm{kPa} \\
\text { Treatment stage }\end{array}$}} & \multirow{2}{*}{\multicolumn{3}{|c|}{$\begin{array}{c}\begin{array}{c}\text { Total yield, } \\
\text { kg/plant }\end{array} \\
\text { Treatment stage }\end{array}$}} \\
\hline & & & & & & & & & \\
\hline & D & $F$ & $\mathrm{H}$ & D & $F$ & $\mathrm{H}$ & $\mathbf{D}$ & $F$ & $\mathbf{H}$ \\
\hline \multicolumn{10}{|c|}{ Drip irrigation system } \\
\hline $100 \%$ & 64.56 & 64.56 & 64.56 & 8.27 & 8.27 & 8.27 & 4.75 & 4.75 & 4.75 \\
\hline $75 \%$ & 52.67 & 55.67 & 58.33 & 12.67 & 14.00 & 15.17 & 4.30 & 3.92 & 4.24 \\
\hline $50 \%$ & 43.17 & 52.67 & 55.33 & 16.83 & 17.67 & 19.03 & 4.02 & 3.68 & 4.09 \\
\hline \multirow{2}{*}{ Average } & 52.28 & 57.34 & 60.89 & 12.17 & 13.22 & 14.68 & 4.36 & 4.12 & 4.36 \\
\hline & \multicolumn{3}{|c|}{56.84} & \multicolumn{3}{|c|}{13.36} & \multicolumn{3}{|c|}{4.28} \\
\hline \multicolumn{10}{|c|}{ Gated pipe irrigation system } \\
\hline $100 \%$ & 64.78 & 64.78 & 64.78 & 7.53 & 7.53 & 7.53 & 4.23 & 4.23 & 4.23 \\
\hline $75 \%$ & 57.67 & 55.53 & 57.67 & 13.17 & 13.67 & 16.67 & 4.06 & 3.86 & 4.04 \\
\hline $50 \%$ & 43.33 & 53.00 & 53.67 & 16.77 & 16.67 & 20.17 & 3.67 & 3.48 & 3.71 \\
\hline \multirow[b]{2}{*}{ Average } & 54.11 & 57.62 & 60.00 & 12.09 & 12.56 & 15.28 & 3.99 & 3.86 & 3.99 \\
\hline & \multicolumn{3}{|c|}{57.24} & \multicolumn{3}{|c|}{13.31} & \multicolumn{3}{|c|}{3.95} \\
\hline $\begin{array}{l}\text { LSD } 05 \quad \text { Irrigation } \\
\text { system, } \mathrm{n}=27\end{array}$ & \multicolumn{3}{|c|}{1.31} & \multicolumn{3}{|c|}{0.39} & \multicolumn{3}{|c|}{$0.15^{\star}$} \\
\hline $\begin{array}{l}\text { LSD } 05 \\
\text { stress, } n=18\end{array}$ & \multicolumn{3}{|c|}{$1.60^{*}$} & \multicolumn{3}{|c|}{$0.47^{*}$} & \multicolumn{3}{|c|}{$0.19^{*}$} \\
\hline $\begin{array}{lr}\text { LSD } & 05 \\
\text { Treatment } & \text { stage, } \\
\mathrm{n}=18 & \\
\end{array}$ & \multicolumn{3}{|c|}{$1.60^{*}$} & \multicolumn{3}{|c|}{$0.47^{*}$} & \multicolumn{3}{|c|}{0.19} \\
\hline
\end{tabular}


J. Soil Sci. and Agric. Eng., Mansoura Univ., Vol.5 (4), April, 2014

F1 


\section{Leaf water potential}

The results demonstrated that tomato leaf water potential values at harvesting stage as affected by irrigation water stress levels 100,75 and 50 $\%$ ETc subjected during development, flowering and harvesting stages under drip irrigation system, were significantly higher than that obtained under gated pipe irrigation system, Table (3) and Fig.(2). This higher values might be attributed to increment of salt accumulation in soil of active root depth under drip irrigation system, consequently, increased tomatoes leaf water potential. The results revealed that tomato leaf water potential values at the end of harvesting stage were significantly increased with increasing irrigation water stress levels 100, 75 and $50 \%$ ETc, subjected during different growth stages under studied irrigation systems. This increase in tomato leaf water potential values might be attributed to increasing soil salinity resulted in deficit of irrigation water. Under drip irrigation system, the leaf water potential values relative to control treatment were increased by $1.53,1.69,1.83$ times and $2.04,2.14,2.30$ times for the plants subjected to water stress levels 75 and $50 \%$ ETc during the development, flowering and harvesting stages, respectively. Under gated pipe irrigation system, the leaf water potential values relative to control treatment were increased by $1.75,1.82 \& 2.21$ times and 2.23, 2.21\& 2.68 times for the plants subjected to water stress levels 75 and $50 \%$ ETc during the development, flowering and harvesting stages, respectively. Consequently, the harvesting stage of tomatoes subjected to irrigation water stress is more affected than other growth stages under studied irrigation system.

\section{Total yield}

The fruit yield of tomatoes, $\mathrm{kg} /$ plant, subjected to irrigation water stress levels 100, 75 and $50 \%$ ETc during development, flowering and harvesting stages under drip irrigation system were significantly higher than that obtained under gated pipe irrigation system, Table (3) and Fig.(3). Data also revealed that fruit yield of tomatoes were significantly decreased with increasing irrigation water stress levels subjected during different growth stages under studied irrigation systems, especially using irrigation water stress level $50 \%$ ETc. This reduction in fruit yield was mainly attributed to the deficit of irrigation water depth and due to the harmful effect in soil salinity in active root zone. In this respect, many investigators found that increasing irrigation water stress decreased the yield of tomatoes, Fisher and Nel (1990) and Mathieu et al., (2007). Under drip irrigation system, fruit yield reduction percentages relative to control treatment were $9.5,17.5 \& 10.7$ and $15.4,22.5$ \& $13.9 \%$ for the plants subjected to irrigation water stress levels 75 and $50 \%$ ETc during the development, flowering and harvesting stages, respectively. Under gated pipe irrigation system, fruit yield reduction percentages relative to control treatment were $4.0,8.7 \& 4.5 \%$ and $13.2,17.7 \& 12.3 \%$ for the plants subjected to irrigation water stress levels 75 and $50 \%$ ETc during the development, flowering and harvesting stages, respectively. Consequently, the flowering growth stage of tomatoes subjected to irrigation water stress is more sensitive than other growth stages under studied irrigation systems. These results are confirmed with Al-Mohammadi and Al-Zu'bi (2011). 
J. Soil Sci. and Agric. Eng., Mansoura Univ., Vol.5 (4), April, 2014

F2 
Shalaby, A. A. et al.

F3

524 


\section{Economical evaluation}

Under studied irrigation systems, the net revenues and invested pound return for tomato yield plant groups $\mathrm{D}, \mathrm{F}$ and $\mathrm{H}$ were decreased with increasing applied irrigation water stress levels 100, 75, 50 \% ETc, Table (4). The net revenues and invested pound return for tomatoes under drip irrigation system were higher than gated pipe irrigation system. Also, the tomato yield plants applied deficit irrigation water during flowering stage (group F) achieved the lowest net revenues and invested pound return at applied irrigation water stress levels \% ETc.

Table (4): Economical evaluation of tomatoes production, thousand Egyptian pounds per hectare, as affected by applied irrigation water stress levels \% ETc under studied irrigation systems.

\begin{tabular}{|c|c|c|c|c|c|}
\hline \multirow[t]{2}{*}{$\begin{array}{l}\text { Irrigation water } \\
\text { stress level } \\
\% \text { ETc }\end{array}$} & \multirow[t]{2}{*}{$\begin{array}{l}\text { Treatment } \\
\text { stage }\end{array}$} & $\begin{array}{l}\text { Average } \\
\text { cost, } \\
\text { LE }\end{array}$ & $\begin{array}{l}\text { Gross } \\
\text { return* }\end{array}$ & $\begin{array}{c}\text { Net } \\
\text { revenues }\end{array}$ & \multirow[t]{2}{*}{$\begin{array}{l}\text { Invested } \\
\text { pound } \\
\text { return }\end{array}$} \\
\hline & & \multicolumn{3}{|c|}{ Thousand Egyptian pounds } & \\
\hline \multicolumn{6}{|c|}{ Drip irrigation system } \\
\hline \multirow{3}{*}{100} & $\mathrm{D}$ & 15.71 & 94.96 & 79.25 & 5.05 \\
\hline & $\mathrm{F}$ & 15.71 & 94.96 & 79.25 & 5.05 \\
\hline & $\mathrm{H}$ & 15.71 & 94.96 & 79.25 & 5.05 \\
\hline \multirow{3}{*}{75} & $\mathrm{D}$ & 15.71 & 85.97 & 70.26 & 4.47 \\
\hline & $\mathrm{F}$ & 15.71 & 78.35 & 62.64 & 3.99 \\
\hline & $\mathrm{H}$ & 15.71 & 84.78 & 69.07 & 4.40 \\
\hline \multirow{3}{*}{50} & $\mathrm{D}$ & 15.71 & 81.97 & 66.26 & 4.22 \\
\hline & $\mathrm{F}$ & 15.71 & 73.57 & 57.86 & 3.68 \\
\hline & $\mathrm{H}$ & 15.71 & 81.78 & 66.07 & 4.21 \\
\hline \multicolumn{6}{|c|}{ Gated pipe irrigation system } \\
\hline \multirow{3}{*}{100} & $\mathrm{D}$ & 15.71 & 84.56 & 68.85 & 4.38 \\
\hline & $\mathrm{F}$ & 15.71 & 84.56 & 68.85 & 4.38 \\
\hline & $\mathrm{H}$ & 15.71 & 84.56 & 68.85 & 4.38 \\
\hline \multirow{3}{*}{75} & $\mathrm{D}$ & 15.71 & 81.16 & 65.45 & 4.17 \\
\hline & $\mathrm{F}$ & 15.71 & 76.97 & 61.26 & 3.90 \\
\hline & $\mathrm{H}$ & 15.71 & 80.97 & 65.26 & 4.15 \\
\hline \multirow{3}{*}{50} & $\mathrm{D}$ & 15.71 & 73.38 & 57.67 & 3.67 \\
\hline & $\mathrm{F}$ & 15.71 & 69.57 & 53.86 & 3.43 \\
\hline & $\mathrm{H}$ & 15.71 & 74.16 & 58.45 & 3.72 \\
\hline
\end{tabular}

${ }^{*}$ The price of one $\mathrm{kg}$ tomatoes is one Egyptian pound at summer 2007.

\section{REFERANCES}

Abdel Gawad, G., A. Arslan, A. Gaihbe and F. Kadouri. 2005. The effects of saline irrigation water management and salt tolerant tomato varieties on sustainable production of tomato in Syria (1999-2002). Agric. Water Manage. 78: 39-53.

Al-Mohammadi1, F. and Y. Al-Zu'bi1. 2011. Soil chemical properties and yield of tomato as influenced by different levels of irrigation water and fertilizer. J. Agr. Sci. Tech. 13: 289-299. 
Allen, R. G., L. S. Pereira, D. Raes and M. Smith. 1998. Crop Evapotranspiration: Guidelines for Computing Crop Water Requirements. FAO, Irrigation and Drainage paper No. 56, Rome, Italy.

Cakir, R. 2004. Effect of water stress at different development stages on vegetative and reproductive growth of corn. Field Crop Res., 89: 1-16.

Doorenbos, J., and A. K. Kassam. 1979. Yield Response to Water. Irrigation and Drainage Paper 33. FAO, United Nations, Rome, p. 176.

Doorenbos, J., and W. O. Pruitt. 1984. Crop Water Requirements. Irrigation and Drainage Paper 24. FAO, United Nations, Rome, p. 144.

El-Neomani, A. A., A. K. A. El Halim, H. A. El Zeynu and A. K. Abd El Halim. 1990. Response of maize (Zea mays L.) to irrigation intervals under different levels of nitrogen fertilization. Egypt. J. Agron. 15: 147-158.

Fisher, H. H., and P. C. Nel. 1990. Deficit drip irrigation of market tomatoes on three soil types. Acta Hortic. 278: 797- 806.

Incalcaterra, G., G. Curatolo, G. Iapichino, A. Pardossi, G. Serra, and F. Tognoni. 2003. Influence of the volume and salinity of irrigation water on winter melon (Cucumis melo inodorus Naud) grown under plastic tunnel. Proceedings of the international symposium on managing greenhouse crops in saline environment, Pisa, Italy, 9-12 July, 2003. Acta Hortic. 609: 423-427.

Jackson, M. L. 1967. Soil Chemical Analysis, Prentice Hall of India, Ltd., New Delhi.

Katerji, N., J. W. van Hoorn, A. Hamdy and M. Mastrorilli. 1998. Response of tomatoes, a crop of indeterminate growth, to soil salinity. Agric. Water Manage. 38: 59-68.

Klute, A. (ed.). 1986. Methods of Soil Analysis. Part 1. Agron. Monogr. 9. ASA and SSSA, Madison, WI.

Mathieu, N., W. Guangyao and G. Ronald. 2007. Withholding of drip irrigation between transplanting and flowering increases the yield of field-grown tomato under plastic mulch. Agric. Water Manage., 87: 285 - 291.

Page, A. L. (ed.). 1982. Methods of Soil Analysis. Part 2. Agron. Monogr. 9. ASA and SSSA, Madison, WI.

Phene, C. J., K. R. Davis, R. B. Hutmacher, and R. L McCormick. 1987. Advantages of subsurface drip irrigation for processing tomatoes. Acta Hortic., 200: 101-113.

Richards, L. A. (ed.). 1954. Diagnosis and Improvement of Saline and Alkali Soils. Agriculture Handbook, No. 60.

Steel, R. G. D. and J. H. Torrie. 1980. Principles and Procedures of Statistics. McGraw-Hill, New York.

Yuan, B., S. Nishiyame, and Y. Kang. 2003. Effects of different irrigation regimes on the growth and yield of drip irrigated potato. Agric. Water Manage. 63: 153-167. 
تأثير الإجتهاد المائي خلال مراحل النمو المختلفة على محصول الطمـاطم تحت نظم

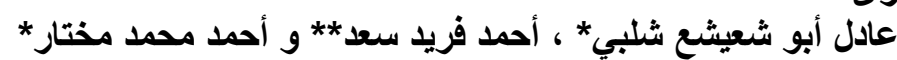

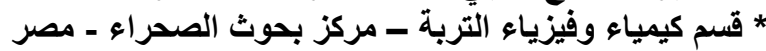

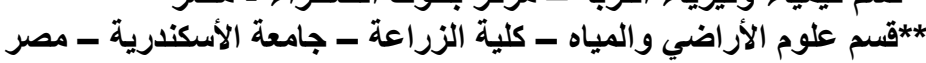

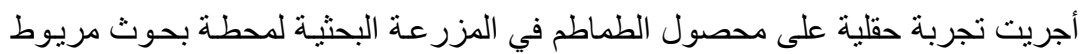

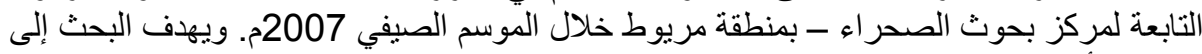

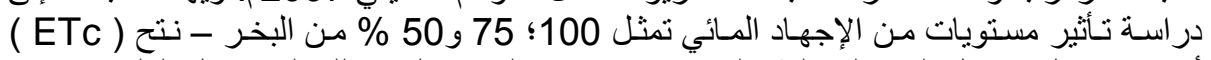

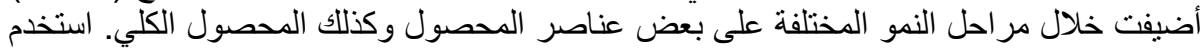

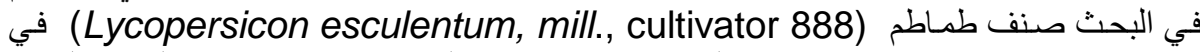

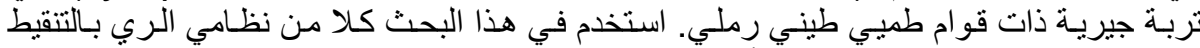

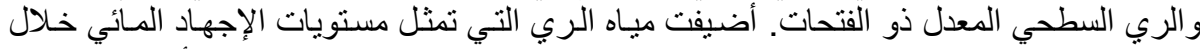

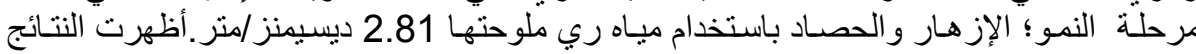

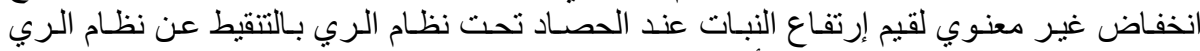

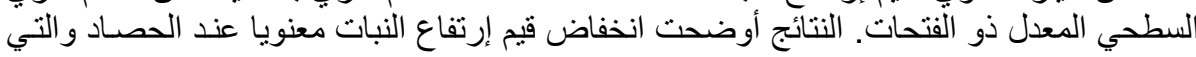

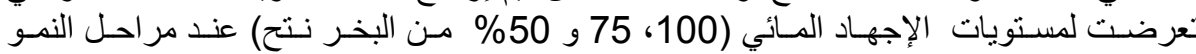

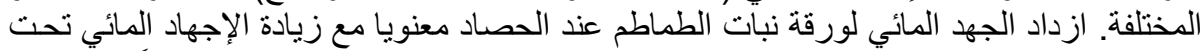

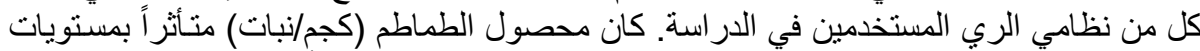

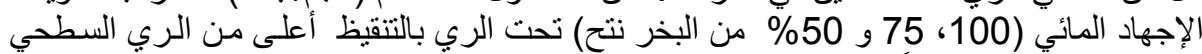
المعدل ذو الفتحات. أيضاً إنخفض محصول

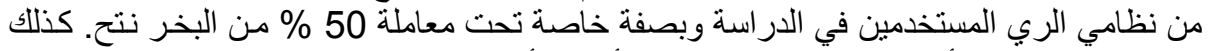

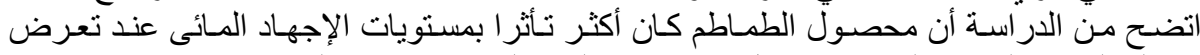

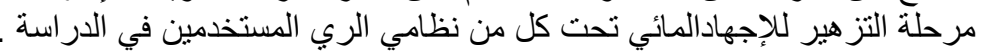

كلية الزراعة - جامعة المنصورة

كلية الزراعة - جامعة الاسكندارية
قأم بتحكيم البحث

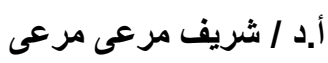


Shalaby, A. A. et al. 

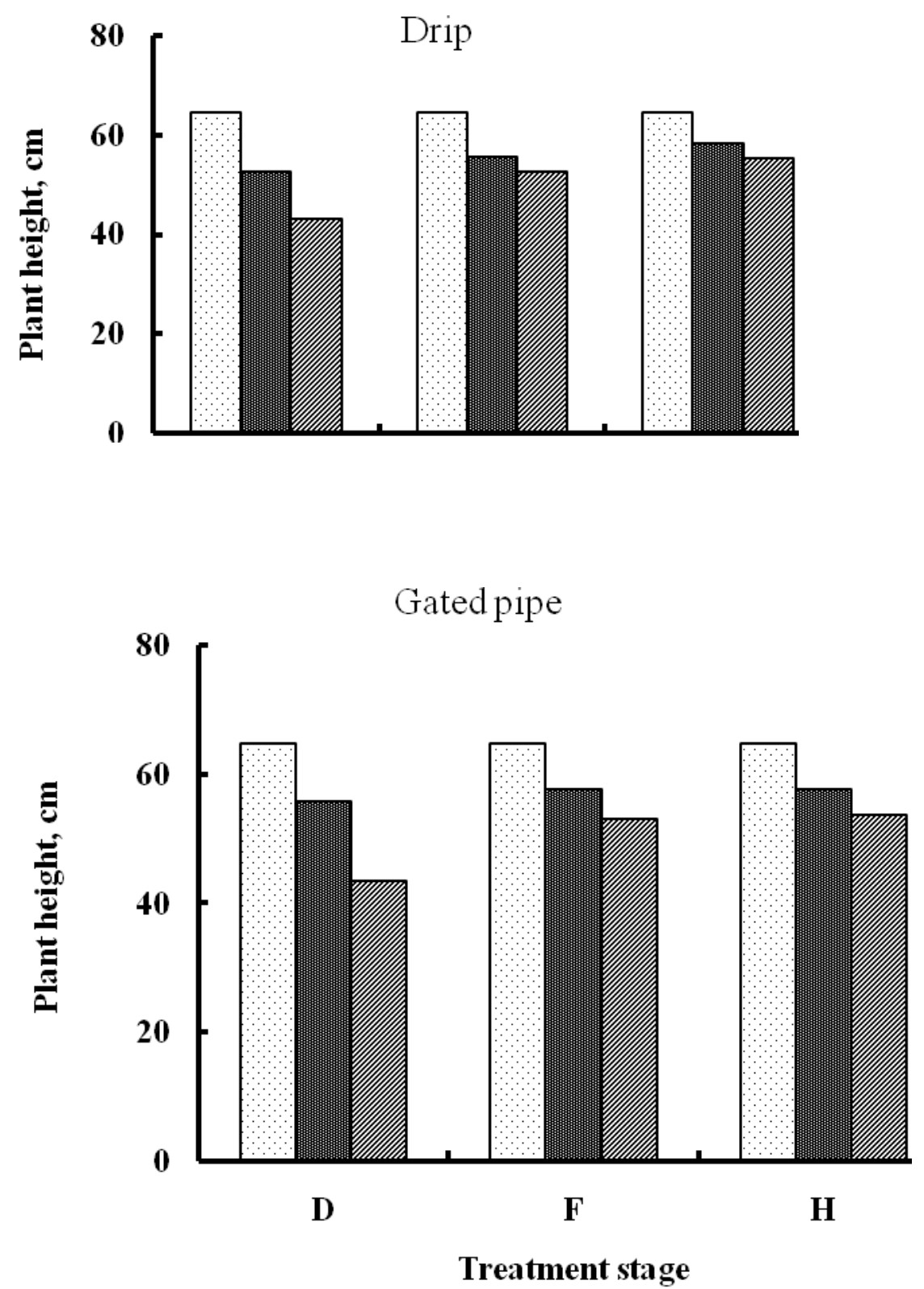

Q100田75 50

Fig. (1): Plant height at harvesting stage as affected by irrigation water stress levels, \% ETc subjected during development, flowering and harvesting stages under studied irrigation systems. 
Shalaby, A. A. et al.

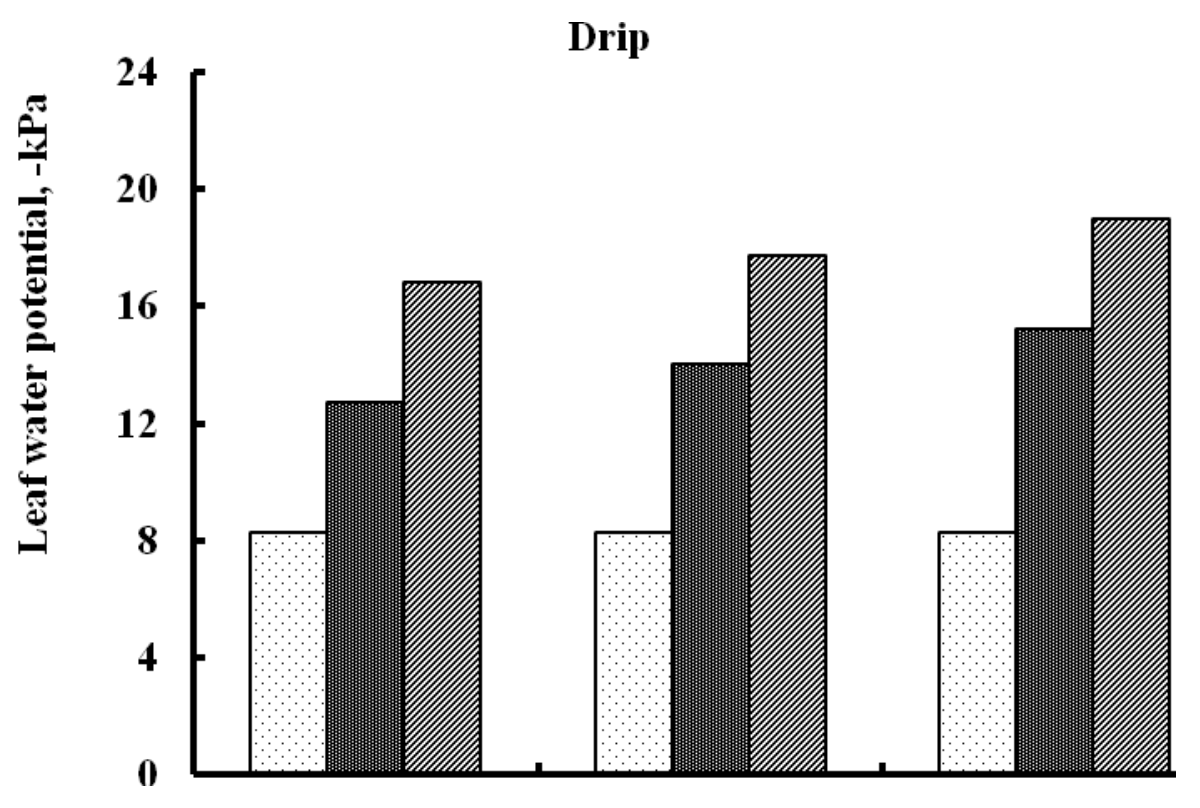




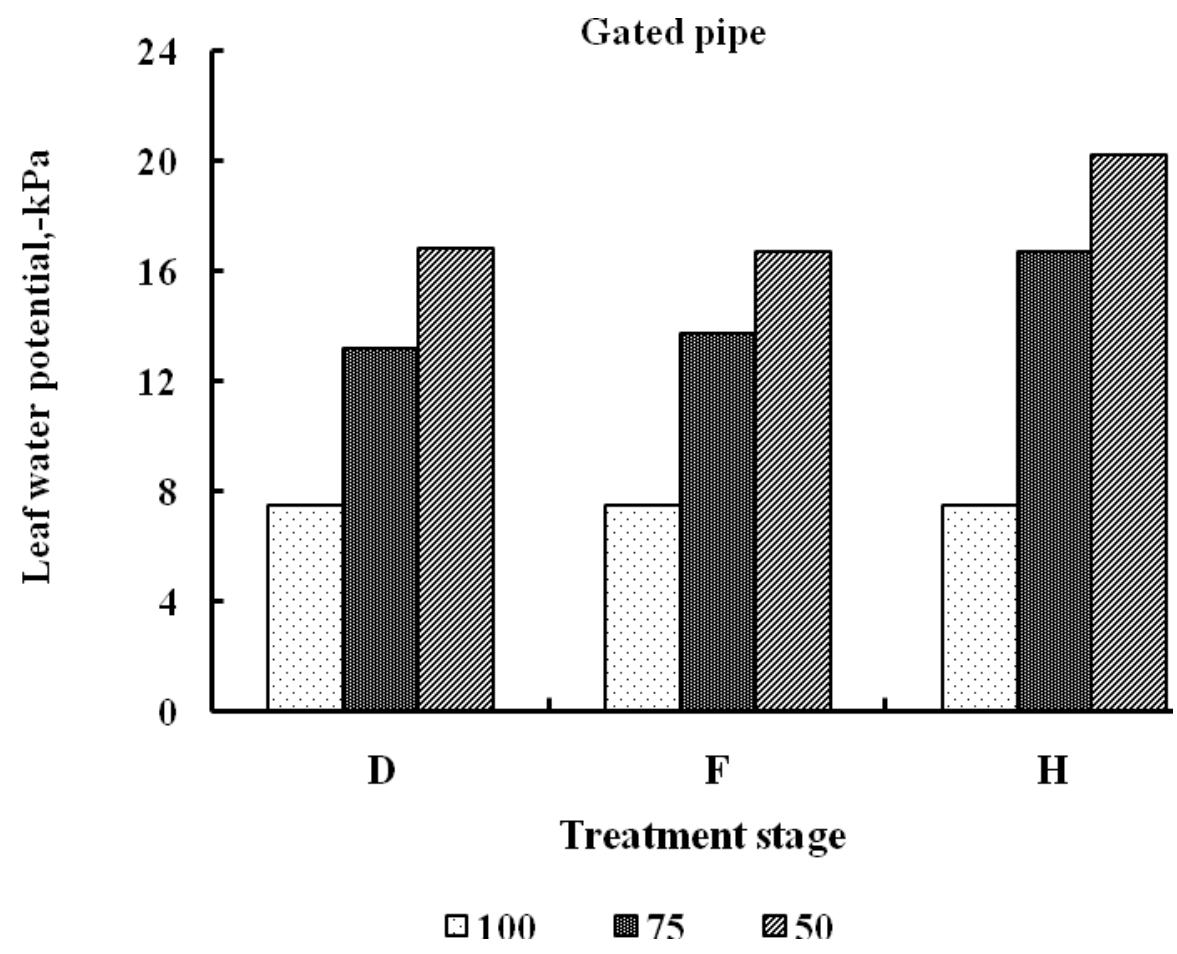

Fig. (2): Plant leaf water potential at harvesting stage as affected by irrigation water stress levels, \% ETc subjected during development, flowering and harvesting stages under studied irrigation systems.
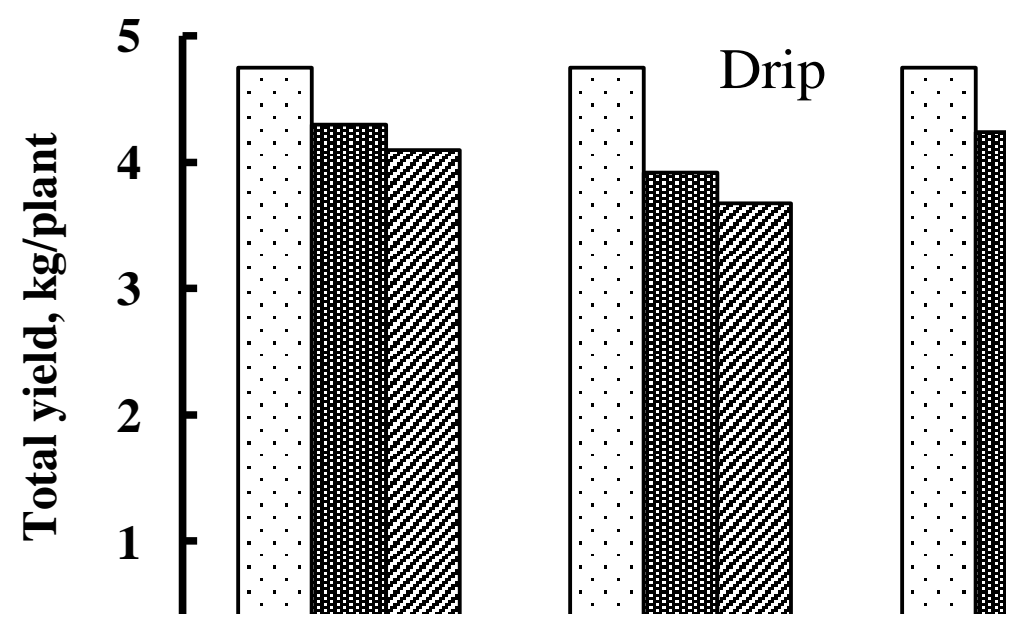


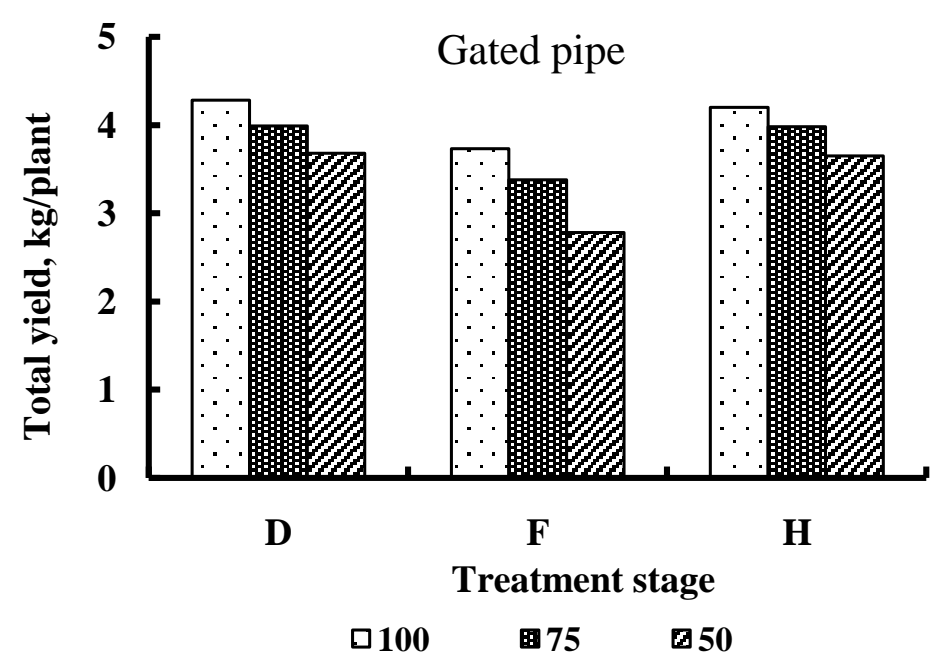

Fig. (3): Plant total yield at harvesting as affected by irrigation water stress levels, \% ETc subjected during development, flowering and harvesting stages under studied irrigation systems. 
J. Soil Sci. and Agric. Eng., Mansoura Univ., Vol.5 (4): 515 - 527, 2014 